\title{
HUBUNGAN SELF-EFFICACY DAN KINERJA PERAWAT DALAM MEMBERIKAN ASUHAN KEPERAWATAN : LITERATURE REVIEW
}

\author{
Tessya Deant Eka Putri, Nelly Febriani \\ Program Studi Keperawatan, Fakultas Ilmu Kesehatan \\ Universitas Pembangunan Nasional Veteran Jakarta
}

\begin{abstract}
ABSTRAK
Kinerja perawat dapat menentukan kualitas pelayanan kesehatan sehingga dibutuhkan perawat yang kompeten. Kinerja perawat dapat didorong dengan self-efficacy yang tinggi sehingga kepercayaan perawat terhadap kemampuannya tinggi karena sifat tidak mudah menyerah dalam menyelesaikan masalah. Tujuannya adalah untuk menganalisis literatur yang berkaitan dengan efikasi diri dan kinerja perawat dalam lima tahun terakhir. Basis data yang digunakan adalah PubMed, Science Direct, EBSCO dan Emerald. Kata kunci yang digunakan adalah perawat, perawat terdaftar, keperawatan, perawat dan efikasi diri, efikasi, kepercayaan diri, kepercayaan diri, kesuksesan dan kinerja perawat, prestasi kerja, kinerja, prestasi kerja. Hasil penelusuran literatur yang diperoleh sebanyak 1.363 artikel. Hasil pencarian melewati proses penyaringan dengan elemen PICO dan metode CRAAP. Hasil penelitian menunjukkan bahwa faktor-faktor yang mempengaruhi kinerja adalah kompetensi, kemandirian, optimisme, dukungan sosial, komitmen, kepemimpinan, pengetahuan, keterampilan dan kemampuan, rendahnya tingkat efikasi diri dan hasil penelitian menunjukkan adanya hubungan antara efikasi diri dengan kinerja perawat $(p<0,01)$. Hal ini penting dilakukan untuk meningkatkan efikasi diri dengan mengadakan pelatihan bagi perawat sehingga dapat meningkatkan rasa percaya diri dan motivasi dalam bekerja.
\end{abstract}

Kata kunci: Perawat, Kinerja Perawat, Self-efficacy

\begin{abstract}
Nurses' performance can determine the quality of health services so competent nurses are needed. Nurse performance can be encouraged by high self-efficacy so that nurses' trust in their abilities is high because of the not giving up nature of solving problems. The aim is to analyze the literature relating to self-efficacy and nurse performance in the past five years. The database's used are PubMed, Science Direct, EBSCO dan Emerald. Keywords used are nurse, registered nurse, nursing, nurses and self-efficacy, efficacy, self belief, confidience, success and nurse performance, work performance, performance, job performance. Literature search results obtained are 1.363 article. The search results pass through the filtering process with PICO elements and CRAAP methods. The results showed that the factors influencing performance were competence, autonomy, optimism, social support, commitment, leadership, knowledge, skills and abilities, low levels of self-efficacy and the results of studies showed a relationship between self-efficacy and nurse performance $(p<0,01)$. It is important to improve self-efficacy by holding training for nurses so as to increase self-confidence and motivation at work.
\end{abstract}

Keywords : Nurse, Nurse performance, Self-efficacy

Alamat Korespondensi: Fakultas Ilmu Kesehatan, Universitas Pembangunan Nasional Veteran Jakarta, Jalan Limo Raya Kelurahan Limo Kecamatan Limo Kota Depok Kode Pos 16515

Email: nellyhassan165@gmail.com 


\section{PENDAHULUAN}

Kinerja perawat yang tidak kompeten dapat mengakibatkan kejadian tidak diharapkan yang akan berdampak pada kualitas pelayanan keperawatan. Penelitian yang dilakukan Triwijayanti \& Romiko (2020) didapatkan bahwa kinerja perawat yang tergolong tidak baik yaitu lebih dari separuh dari total perawat yaitu sebanyak 32 perawat (56.1\%) sehingga kinerja yang dihasilkan tidak optimal. Fatimah \& Rosa (2016) menyebutkan dalam hasil penelitiannya bahwa kesalahan pemberian obat yang paling banyak yaitu pada pasien sebesar 59,4\% akibat kinerja perawat yang kurang optimal. Maka dapat disimpulkan bahwa kinerja perawat yang tidak baik sudah lebih dari separuhnya dan jika tidak diberikan penyelesaian maka dapat menyebabkan penurunan pada kualitas pelayanan.

Tingkatan self-efficacy dapat menentukan seberapa besar kepercayaan perawat terhadap kemampuan yang dimiliki sehingga keyakinan ini yang akan menentukan kualitas kinerja. Program pengembangan kompetensi yang profesional dapat mendukung peningkatan selfefficacy yang dirasakan oleh perawat yang berguna untuk meningkatkan kepercayaan akan kemampuan perawat dalam mengembangkan hubungan yang penuh perhatian dengan pasien sehingga terjadi peningkatan pada kepuasan pasien selama proses asuhan keperawatan berlangsung (Reid, Jones, Hurst, \& Anderson, 2018). Maka dapat disimpulkan bahwa perawat yang memiliki tingkat self-efficacy tinggi akan mempengaruhi perawat dalam meningkatkan sikap peduli dan perhatian saat memberikan asuhan keperawatan kepada pasien sehingga tingkat kepuasan pasien akan meningkat.

Permasalahan diatas menunjukan bahwa kinerja perawat menentukan kualitas dari pelayanan kesehatan sehingga diperlukan perawat yang kompeten dalam menjalankan tugasnya. Perawat harus mampu memberikan asuhan keperawatan sesuai dengan standar kompetensi perawat (Hutahaean, 2020). Hal ini dapat didorong dengan tingkat self-efficacy yang tinggi sehingga perawat memiliki sifat pantang menyerah dan yakin terhadap kemampuan yang dimilikinya. Bandura, (1991) dalam Pupuk et al., (2018) menyatakan bahwa ciri dari self-efficacy yang tinggi adalah gigih, mengerjakan tugas tertentu walaupun dinilai sulit, dan suka mencari situasi baru serta dapat mencapai hasil yang diharapkan dengan kinerja yang baik karena individu yang memiliki self-efficacy tinggi memiliki motivasi yang kuat dan emosi yang lebih stabil. Maka dari itu individu yang berusaha keras dalam menyelesaikan tugasnya karena memiliki kepercayaan yang tinggi akan kemampuannya dapat menghasilkan kinerja yang baik.

Fenomena yang ditemukan oleh peneliti secara langsung didapatkan ketika menjalani praktik klinik di Rumah Sakit Umum Daerah Pasar Minggu pada tahun 2019 dimana terdapat perawat yang baru lulus dan bekerja masih membutuhkan pengawasan dari perawat senior karena sedikit kurang percaya diri dalam memberikan asuhan keperawatan secara mandiri. Namun, setelah beberapa minggu bekerja, perawat merasa lebih percaya diri untuk memberikan perawatan kepada pasien secara mandiri. Oleh karena itu peneliti tertarik untuk menganalisis hubungan self-efficacy dengan kinerja pada perawat karena fenomena tersebut.

\section{METODE}

Data yang digunakan dalam penelitian ini merupakan data sekunder yaitu dengan rancangan penelitian literature review karena data diambil dari penelitian yang sudah dilakukan dan bukan dari pengamatan secara langsung. Peneliti mengumpulkan jurnal artikel dari database yang dapat dipercaya. Database yang peneliti gunakan untuk mencari jurnal yang berkaitan dengan judul penelitian yaitu antara lain PubMed, Science Direct, EBSCO dan Emerald. Artikel penelitian yang dicari dan dipilih adalah jurnal yang diterbitkan pada tahun 2015 sampai 2020. Strategi pencarian pada literatur penelitian ini menggunakan kata kunci dalam bahasa inggris dengan menggunakan kombinasi boolean dari setiap elemen PICOS yaitu yaitu ("nurse" OR "registered nurse" OR "nursing" OR "nurses" OR "nursing") 
AND ("self-efficacy" OR "efficacy" OR "self belief OR "confidience" OR "success") AND ("nurse performance" OR "work performance" OR "performance" OR "job performance"). Kriteria Inklusi pada penelitian ini yaitu jurnal atau artikel yang sesuai dengan elemen PICOS yaitu populasi dalam penelitian yaitu perawat, intervensi penelitian yaitu self-efficacy, outcome pada penelitian ini yatu kinerja, dan study type yang terdiri dari bahasa yaitu bahasa inggris, pembatasan tahun publikasi yaitu lima tahun terakhir dan jenis penelitian yaitu desain cross sectional, experiment, dan randomized controlled trial.

Artikel yang dipilih merupakan artikel yang dapat menjawab pertanyaan review dan telah disaring berdasarkan metode kriteria evaluasi CRAAP yang merupakan singkatan dari currency, relevance, authority, accuracy, dan purpose yaitu dimana sebanyak 1,280 artikel yang tidak sesuai pada penyaringan pertama dan penyisihan 40 artikel pada penyaringan tahap kedua. Artikel yang tidak dipilih adalah artikel penelitian yang dinilai tidak dapat menjawab pertanyaan penelitian setelah ditinjau menggunakan metode kriteria evaluasi CRRAP (currency, relevance, authority, accuracy, purpose) maka terpilihlah 4 artikel yang sesuai dengan tujuan penelitian dan dapat menjawab pertanyaan penelitian.

\section{HASIL}

Dari hasil pencarian studi atau artikel, ditemukan dua studi dengan desain eksperimen , satu studi dengan desain cross sectional, dan dua studi dengan desain descriptive correlational. Secara keseluruhan, desain yang paling banyak digunakan yaitu eksperimen. Desain eksperimen yang diambil yaitu jurnal yang menjelaskan pengaruh dari self-efficacy pada perawat dengan kinerja dalam memberikan asuhan keperawatan yaitu perawatan pada pasien COPD dan $\mathrm{CHF}$ dengan perawatan tracheostomy dan perawatan laryngectomy. Penelitian desain descriptive correlational yaitu membahas hubungan antara self-efficacy dan kinerja kepala perawat dengan kinerja. Untuk lebih jelasnya dapat dilihat dari tabel 4 daftar artikel hasil pencarian.

Artikel yang masuk kedalam studi inklusi rata-rata dilakukan dinegara Amerika Serikat yaitu berjumlah dua studi (Genuino, 2018 ; McDonough et al., 2016), satu studi dilakukan di Mesir (Elhamed, Seham 2019) dan yang lainnya dilakukan di Maladewa (Jeeza et al., 2015). Dua studi tentang kinerja pada perawat menunjukan bahwa kinerja terdapat pada tingkat tinggi dan dua studi menghasilkan kinerja yang rendah. Satu studi menunjukkan self-efficacy pada perawat rendah dan dua studi menunjukkan self-efficacy tinggi. Empat studi menunjukan adanya hubungan antara self-efficacy dan kinerja pada perawat 
Tabel 1 Daftar Artikel Hasil Pencarian

\begin{tabular}{|c|c|c|c|c|c|c|c|}
\hline No & Author & Tahun & $\begin{array}{l}\text { Volume, } \\
\text { Angka }\end{array}$ & Judul & $\begin{array}{c}\text { Metode (Desain, Sampel, Variabel, } \\
\text { Instrument, Analisis) }\end{array}$ & Hasil Penelitian & Database \\
\hline 1 & $\begin{array}{l}\text { Jeeza, } \\
\text { Hassan } \\
\text { Hongkrailert, } \\
\text { Nate } \\
\text { Sillabutra, } \\
\text { Jutatip }\end{array}$ & 2015 & $\begin{array}{l}\text { Journal of } \\
\text { Public } \\
\text { Health and } \\
\text { Development } \\
\text { Vol. } 13 \text { No. } 2\end{array}$ & $\begin{array}{l}\text { Effect of } \\
\text { efficacy on } \\
\text { nursing } \\
\text { performance } \\
\text { in Indira } \\
\text { Gandhi } \\
\text { Memorial } \\
\text { Hospital, } \\
\text { Maldives }\end{array}$ & $\begin{array}{l}\text { Desain : Penelitian deskriptif cross- } \\
\text { sectional } \\
\text { Sampel : } 238 \text { nurses } \\
\text { Instrumen : Instrumen penelitian terdiri } \\
\text { dari empat bagian yaitu: } \\
\text { a. Data demografi yang terdiri dari } \\
\text { informasi dasar tentang perawat } \\
\text { seperti usia, jenis kelamin, status } \\
\text { perkawinan, status pekerjaan } \\
\text { dan jumlah anak. } \\
\text { b. Skala self-efficacy berdasarkan } \\
\text { panduan Bandura untuk } \\
\text { membangun skala efficacy yang } \\
\text { terdiri dari total } 24 \text { pernyataan } \\
\text { menggunakan skala Likert } 6 \text { poin } \\
\text { mulai dari } 1=\text { sangat setuju; } 2= \\
\text { agak setuju; } 3=\text { setuju, } 4=\text { agak } \\
\text { tidak setuju, } 5=\text { tidak setuju; dan } \\
6=\text { Sangat tidak setuju } \\
\text { Skala efikasi kolektif berdasarkan } \\
\text { skala kepercayaan efikasi pribadi } \\
\text { oleh Riggs dan Knight (1994) } \\
\text { yang terdiri dari total } 27 \\
\text { pernyataan menggunakan skala } \\
\text { Likert } 6 \text { poin mulai dari } 1= \\
\text { sangat setuju; } 2=\text { agak setuju; } 3= \\
\text { setuju, } 4=\text { agak tidak setuju, } 5= \\
\text { tidak setuju; dan } 6=\text { Sangat tidak } \\
\text { setuju }\end{array}$ & $\begin{array}{l}\text { Kinerja pada keseluruhan tugas } \\
\text { yang dirasakan oleh perawat } \\
\text { berada di tingkat yang lebih } \\
\text { tinggi dan keseluruhan kinerja } \\
\text { kontekstual berada pada level } \\
\text { sedang. Ada korelasi antara } \\
\text { kinerja keperawatan dan self- } \\
\text { efficacy (p<0,01). }\end{array}$ & Pubmed \\
\hline
\end{tabular}




\section{Skala kinerja keperawatan, \\ terdiri dari 25 item; 11 item \\ dalam tiga dimensi kinerja tugas; \\ 14 item dalam tiga dimensi \\ kinerja kontekstual \\ menggunakan skala Likert 7 poin \\ $(1=$ buruk; 2 = di \\ bawah baik; 3 = Fairley baik; $4=$ \\ baik; 5 = agak di atas baik; $6=$ \\ sangat baik; 7 = sangat baik) \\ digunakan.}

Analisis : Korelasi Pearson

2 Mary Jane Genuino

3 Seham

Mohamed

Abd

Elhamed,

Sahar
Applied

Nursing

Research

2019

Port Said

Scientific

Journal of

Nursing
Effects of

simulation-

based

educational

program in

improving

the nurses'

self-efficacy

in caring for

patients' with

COPD and

$\mathrm{CHF}$ in a

post-acute

care (PACU)

setting

Relationship

between

Head Nurses

Self-efficacy
Desain : Desain Eksperimen

Sampel : 16 perawat

Analisis : T-Test

Desain : Desain penelitian deskriptif

Sampel : Terdiri dari 44 kepala perawat

Instrumen :

a. Bagian Pertama
Skor self-efficacy post-stimulasi dari partisipan menunjukkan peningkatan sekitar 5 persen

dibandingkan dengan skor prasimulasi dimana menunjukkan program pendidikan berbasis simulasi sebagai efek pada efikasi diri peserta pascasimulasi.

Mayoritas kepala perawat (82\%) Emerald mempunyai efikasi diri rendah dan lebih dari separuhnya (59\%)
Science

Direct 


$\begin{array}{lll}\text { Mohamed } & \text { Volume } 7 & \text { and Job } \\ \text { Morsy \& } & \text { No.19 } & \text { Performance } \\ \text { Amal Sayed } & & \end{array}$

1) Lembar data demografi yang terdiri dari jenis kelamin, usia, pengalaman bertahuntahun, kualifikasi pendidikan, dan status perkawinan

2) Penilaian efikasi terdiri dari skala yang mencakup 50 item pernyataan Skala penilaian efikasi diri yang kinerja tidak memadai. Tidak ada perbedaan signifikan secara statistik antara data pribadi dengan efikasi dan kinerja kepala perawat.Terdapat hubungan yang positif antara self-efficacy pada kepala perawat dan kinerja.

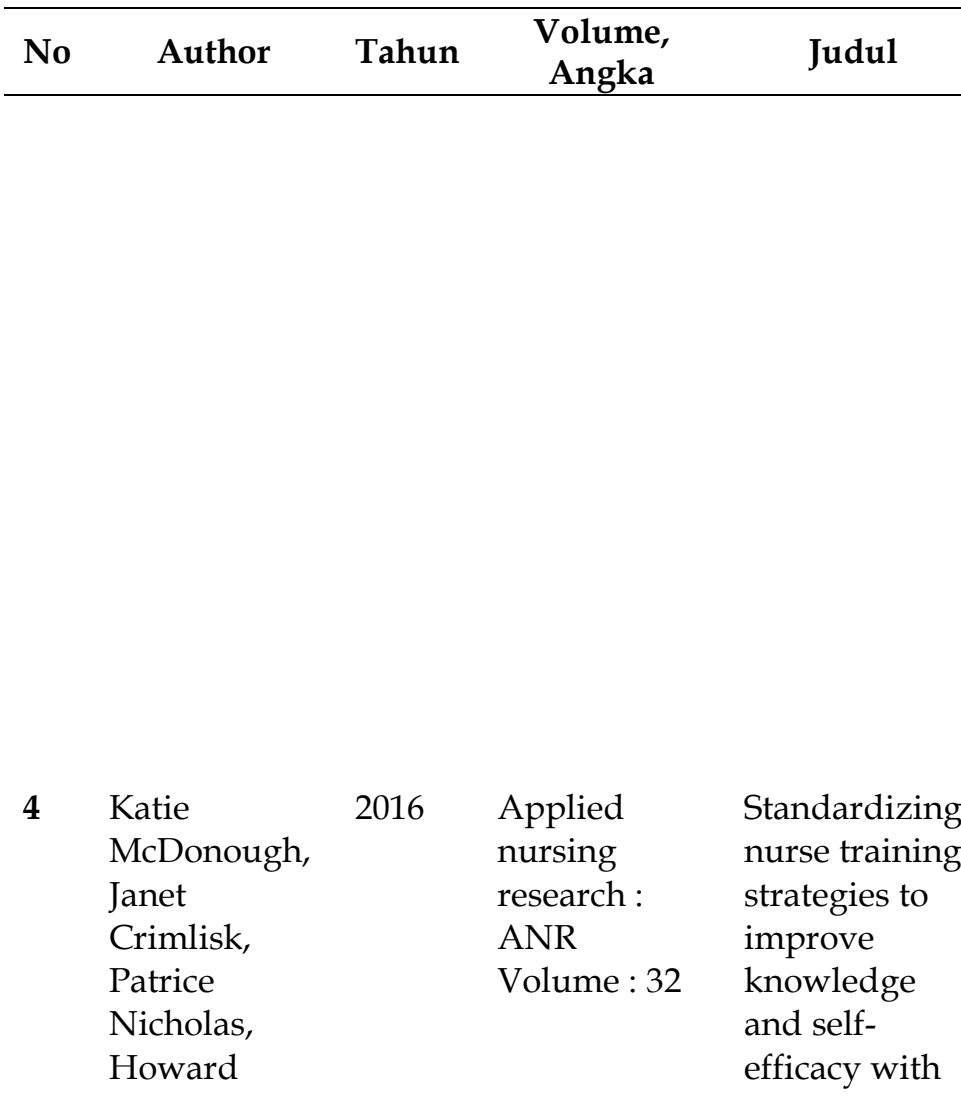

Metode (Desain, Sampel, Variabel, Instrument, Analisis)

dikembangkan oleh El-Adel,

(2001) yang setiap

pertanyaan menggunakan 4

poin skala penilaian yang

berkisar dari (1) untuk

jarang, (2) untuk terkadang,

(3) untuk sering dan (4)

untuk selalu.

b. Bagian Kedua

Lembar daftar periksa prestasi

kerja yang mencakup 3 kategori

utama (karakteristik umum, soft

skill, dan asuhan keperawatan).

Analisis : Regresi berganda dan korelasi matriks.

Desain : Desain survei intervensi

Sampel : 338 Sampel

\section{Instrumen :}

a. Kuisioner Pengetahuan termasuk pertanyaan tentang perawatan stoma yang tepat, pertanyaan anatomi yang
Efikasi diri yang rendah akan Science menurunkan kemampuan Direct perawat untuk berhasil melakukan asuhan keperawatan trakeostomi dan perawatan laringektomi. Survei data menunjukkan bahwa $19 \%$ 
Cabral,

Emily K.

Quinn,

Scharukh

Jalisi tracheostomy

and

laryngectomy

care. mengidentifikasi perbedaan antara trakeostomi dan

laryngectomy

b. Pertanyaan self-efficacy menggunakan skala Likert dan termasuk sangat setuju, agak setuju, agak tidak setuju dan sangat tidak setuju. Skala The Personal Efficacy Beliefs scale

milik Riggs dan Knight telah dimodifikasi, dan versi yang diadaptasi divalidasi sebelum digunakan

Analisis : Chi-square dan T-Test responden meragukan

kemampuan untuk melakukan perawatan trakeostomi rutin dan

$50 \%$ responden meragukan

kemampuan untuk melakukan perawatan laringektomi rutin.

Sebanyak40\% responden meragukan kemampuan untuk melakukan perawatan trakeostomi darurat dan 62\% dari mereka

meragukan kemampuan untuk melakukan laryngectomy darurat. Hampir separuh (46\%) responden tidak nyaman melakukan tugas yang terlibat dengan perawatan trakeostomi, dan $67 \%$ tidak nyaman 


\section{PEMBAHASAN}

\section{Kualitas Kinerja Perawat dalam Memberikan Asuhan Keperawatan}

Kinerja pada perawat dilihat dari kualitas pelaksanaan asuhan keperawatan kepada pasien mulai dari pengkajian pada saat pasien masuk ruangan sampai evaluasi pada saat pasien diperbolehkan untuk pulang. Kurniadi (2016) menjelaskan bahwa kinerja keperawatan adalah prestasi kerja yang dihasilkan oleh perawat dalam melaksanakan tanggung jawab dengan memberikan asuhan keperawatan yang baik sehingga dapat menghasilkan pencapaian yang diharapkan oleh organisasi, perawat sendiri, maupun pasien dalam kurun waktu tertentu serta memiliki tanda bahwa tingkat kepuasan pasien dan zero complain dari pasien. Maka dapat disimpulkan bahwa kinerja perawat dalam memberikan asuhan keperawatan merupakan tanggung gugat perawat dalam melaksanakan tanggung jawabnya dan kualitas kinerja akan mempengaruhi tingkat kepuasan pasien.

Kinerja pada perawat akan dinilai kualitasnya pada saat penilaian kinerja dan dilihat tinggi atau rendahnya kualitas kinerja perawat dalam memberikan asuhan keperawatan. Hasil dari kinerja perawat yang didapatkan dari hasil penelitian oleh Jeeza et al., (2015) yaitu berada di tingkatan tinggi (mean $=59.02, S D=11.97)$. Selain itu, dimensi penyediaan informasi dan dimensi perawatan teknis perawat juga berada di tingkat tinggi walaupun dukungan sosial yang didapat dari lingkungan berada pada tingkat sedang. Hal ini disebabkan perawat menunjukkan optimisme, kompetensi, komitmen, dukungan sosial dan otonomi kerja serta pengambilan keputusan sebagai faktor yang sangat kuat dalam keseluruhan kinerja perawat ( $p$-value $<0,05)$ (Jeeza et al., 2015).

Pelatihan dan penilaian pada perawat akan menentukan kualitas pada kinerja perawat yang dihasilkan. Elhamed, (2019) mendapatkan hasil bahwa lebih dari setengah kepala perawat memiliki kinerja pekerjaan yang tidak memadai $(59 \%)$. Hal ini disebabkan oleh kurangnya pelatihan dan bimbingan mengenai otonomi dan manajemen diri yang dapat mengarah pada penurunan kinerja kepala perawat. Salah satu faktor yang mempengaruhi kinerja menurut Ilyas dalam Kurniadi (2016) yaitu faktor organisasi dimana dukungan dari organisasi sangat penting bagi pegawai dalam menyelesaikan tugas yang diberikan seperti suasana kerja didalam institusi dan kemampuan pegawai dalam menyelesaikain tugasnya yaitu strategi, kompensasi, sistem manajemen dan dukungan sumber daya. Maka dapat disimpulkkan dengan adanya pelatihan dan bimbingan pada perawat dapat meningkatkan kualitas perawat dalam memberikan asuhan keperawatan.

Kinerja keperawatan tidak hanya dipengaruhi oleh lingkungan dan organisasi, namun juga salah satu faktor dalam individu seperti kepribadian, kompetensi maupun pengetahuan. Penelitian yang dilakukan oleh McDonough et al., (2016) mendapatkan bahwa sebesar 70\% responden melaporkan bahwa mereka merasa tidak nyaman dengan aspek perawatan trakeostomi karena kurangnya pengetahuan mereka, dan sebesar $81 \%$ responden merasa tidak nyaman dengan aspek perawatan laringektomi juga karena kurangnya pengetahuan mereka. Hal ini sejalan dengan salah satu dimensi kinerja yaitu job knowledge menurut Gomes (1997) dalam Kurniadi (2016) dimana pengetahuan seputar pekerjaan berarti luasnya pengetahuan pegawai mengenai pekerjaan dan kompetensi yang dimiliki. Sehingga dapat disimpulkan bahwa semakin luas pengetahuan dan kompetensi yang dimiliki perawat maka dapat semakin baik kinerja perawat dalam memberikan asuhan keperawatan.

\section{Tingkat Self-Efficacy pada Perawat}

Kepercayaan diri yang dimiliki dapat membantu individu dalam mencapai tujuannya. Bandura (1997) dalam Dewi Octavia Tumurang, Ventje Ilat, (2019) menyatakan bahwa selfefficacy atau efikasi diri adalah kepercayaan individu terhadap kemampuan dirinya dalam melakukan tugas atau tanggung jawabnya untuk mencapai suatu pencapaian hasil yang 
diharapkan. BorjAlilu, S. et al (2017) menyatakan definisi dari self-efficacy merupakan suatu hasil dari reaksi emosional dan pola pikir yang membentuk suatu perilaku individu. Sehingga dapat disimpulkan bahwa self-efficacy berasal dari persepsi individu sehingga menghasilkan keyakinan dirinya mengenai kemampuan dan kompetensi dirinya dalam mengatasi masalah sehingga tujuan yang diharapkan dapat tercapai.

Self-efficacy yang terlihat pada hasil penelitian yang dilakukan oleh Elhamed, (2019) menunjukan mayoritas kepala perawat memiliki self-efficacy yang rendah yaitu sebesar $82 \%$ dari 44 kepala perawat. Sedangkan minoritas kepala perawat yang memiliki self-efficacy yang tinggi yaitu hanya sebesar $4 \%$. Hal ini tidak sejalan dengan teori yang dikemukakan oleh Bandura, (1997) dalam Mahmudi \& Suroso, (2015) mengenai faktor yang mempengaruhi selfefficacy yakni dimana tingkat self-efficacy seseorang akan berbanding lurus dengan status individu tersebut di lingkungannya karena semakin tinggi status yang dimiliki, semakin tinggi juga self-efficacy yang dimiliki. Maka dapat disimpulkan bahwa terdapat kesenjangan antara hasil penelitian dengan teori bahwa status individu yang ditunjukan oleh kepala perawat dalam penelitian dimana kedudukannya lebih tinggi dibanding perawat pelaksana tidak mempengaruhi tingkat self-efficacy.

Tingkat self-efficacy yang rendah dapat mempengaruhi perilaku dan kemampuan yang dimiliki individu. Pada penelitian McDonough et al., (2016) menunjukkan perawat memiliki efikasi diri yang rendah. Survei data menunjukkan bahwa 19\% responden meragukan kemampuan mereka untuk melakukan perawatan trakeostomi rutin dan $50 \%$ responden meragukan kemampuan mereka untuk melakukan perawatan laringektomi rutin. Selanjutnya, $40 \%$ responden meragukan kemampuan mereka untuk melakukan perawatan trakeostomi darurat dan $62 \%$ dari mereka responden meragukan kemampuan mereka untuk melakukan laryngectomy darurat peduli. Perawatan keperawatan untuk pasien-pasien ini secara teknis juga tidak sulit. Maka dapat disimpulkan bahwa self-efficacy yang rendah dapat menyebabkan keraguan dan fokus kepada kekurangan yang dimiliki sehingga kinerja yang dihasilkan tidak adekuat.

\section{Hubungan Self-efficacy dan Kinerja Perawat dalam Memberikan Asuhan Keperawatan}

Hubungan antara self-efficacy dengan kinerja perawat pada hasil penelitian yang dilakukan oleh Jeeza et al., (2015) menunjukan bahwa terdapat kolerasi positif yang signifikan antara self-efficacy dan kinerja. Bandura, (1978) mengemukakan bahwa tingkat efikasi yang tinggi mendorong pemikiran positif dan peningkatan kinerja serta mendefinisikan self-efficacy sebagai individu yang percaya tentang kemampuan mereka untuk menghasilkan tingkat kinerja yang ingin dicapai dan mampu melakukan tugas yang diberikan. Di Rumah Sakit Memorial Indira Gandhi (IGMH) menunjukan bahwa sebagian besar perawat terlibat dalam melakukan tugasnya yaitu memberi asuhan keperawatan, dan untuk menjaga interaksi dengan pasien yang lebih baik, beban kerja dan rasio antara pasien dan perawat maka administrasi rumah sakit telah memberikan prioritas untuk meningkatkan jumlah perawat (Jeeza et al., 2015). Maka dapat disimpulkan bahwa peran dari keterlibatan perawat dalam melaksanakan tugasnya dan dukungan sumber daya dari organisasi dapat mempengaruhi tingkat self-efficacy dan kinerja yang dihasilkan.

Self-efficacy yang tinggi akan meningkatkan kepercayaan diri perawat dalam merawat pasien dengan kasus yang membutuhkan kompetensi dan skill tertentu. Genuino, (2018) menjelaskan dalam hasil penelitiannya yang menggunakan intervensi simulasi perawatan pada pasien dengan Chronic obstuctive pulmonary disease (COPD) dan Heart Failure (HF) pada self-efficacy perawat yaitu menunjukan bahwa skor efikasi diri post-stimulasi dari peserta menunjukkan peningkatan sekitar 5\%. Perawatan pada pasien lansia yang rentan ini sangat rumit dan membutuhkan keterampilan tertentu mengingat faktor usia disertai penyakit komorbid menyebabkan pasien tinggal lebih lama di ruangan Post Anesthesia Care Unit (PACU). Self-efficacy yang tinggi akan membuat perawat tertarik untuk melakukan usaha 
lebih keras dan tidak mudah putus asa (Bandura, 1986 dalam Jannah, Supriadi, \& Suri , 2019). Sehingga dapat disimpulkan bahwa dengan meningkatnya self-efficacy pada perawat akan membuat perawat yang melakukan perawatan pada pasien COPD dan HF menganggap tugas yang sulit sebagai tantangan untuk diatasi sehingga usaha yang diberikan akan lebih keras dan gigih.

Hubungan self-efficacy dengan kinerja kepala perawat dapat dilihat dari hasil penelitian yang dilakukan oleh Elhamed, Seham (2019) yang menunjukan terdapat hubungan positif sedang antara self-efficacy dengan kinerja kepala perawat. Hal ini menunjukan bahwa salah satu faktor yang mempengaruhi adalah faktor psikologis dimana faktor psikologis mencakup motivasi belajar, sikap, kepribadian dan persepsi pegawai terhadap pekerjaannya berpengaruh terhadap kinerja pegawai (Kurniadi, 2016). Maka dapat disimpulkan bahwa self-efficacy yang membentuk motivasi akan mempengaruhi kepala perawat dalam menjalankan tugasnya. Jika self-efficacy pada perawat rendah, maka kepala perawat tidak berpikir mengenai bagaimana cara yang baik dalam menyelesaikan tugas dan tidak mempedulikan besarnya kemampuan yang dimiliki.

Individu yang memiliki tingkat self-efficacy yang rendah cenderung meragukan kemampuannya dan memikirkan kekurangan dalam dirinya sehingga kinerja yang dihasilkan tidak maksimal. McDonough et al., (2016) dalam penelitiannya menunjukan bahwa self-efficacy yang rendah akan merusak kemampuan perawat untuk berhasil mengelola pasien dengan perawatan trakeostomi dan perawatan laringektomi. Data menunjukkan bahwa 19\% responden meragukan kemampuan mereka untuk melakukan perawatan trakeostomi rutin dan 50\% responden meragukan kemampuan mereka untuk melakukan perawatan laringektomi rutin. Self-efficacy yang rendah akan mengakibatkan kinerja yang dihasilkan menjadi tidak baik, salah satunya yaitu perawatan pada pasien dengan laringektomi dan trakeostomi rutin. Perawat merasa tidak dapat menyelesaikannya dan tidak yakin dengan kemampuan yang dimiliki karena sibuk memikirkan kekurangan dan kemungkinan kegagalan yang akan terjadi. Hal ini perlu dibenahi dan diperbaiki karena dengan tingkat kepercayaan diri perawat yang tinggi akan memaksimalkan kualitas kinerja perawat baik dalam perawatan pasien dengan laringektomi dan trakeostomi maupun perawatan yang lainnya.

\section{SIMPULAN}

Maka dapat disimpulkan bahwa hasil yang didapatkan dari beberapa artikel berbedabeda sehingga self-efficacy belum bisa dipastikan secara pasti dapat mempengaruhi kinerja perawat dalam melaksanakan asuhan keperawatan kepada pasien. Namun, mayoritas dari hasil penelitian menunjukan adanya hubungan antara self-efficacy dengan kinerja perawat dalam melakukan asuhan keperawatan. Faktor yang dapat mempengaruhi kinerja yaitu kompetensi, otonomi, pengambilan keputusan, optimisme, dukungan sosial, komitmen dan dukungan sumber daya serta kemampuan perawat dalam memberikan perawatan, gaya kepemimpinan direktur keperawatan yang otokratis dan kurangnya pelatihan mengenai manajemen diri serta upaya atau bimbingan mengenai self-efficacy yang rendah dan pengetahuan.

Maka dari itu merupakan hal yang penting untuk meningkatkan self-efficacy pada perawat karena dengan adanya self-efficacy yang tinggi akan menjadikan kinerja lebih baik sebab perawat yakin terhadap kemampuan diri sendiri, pantang menyerah, dan gigih dalam mengerjakan tugas tertentu walaupun dinilai sulit, dan suka mencari situasi baru sehingga mereka dapat mencapai hasil yang diharapkan. Pelatihan self-efficacy dibutuhkan agar menunjang kinerja perawat sesuai dengan yang diharapkan sehingga mutu pelayanan kesehatan dapat meningkat. 


\section{DAFTAR PUSTAKA}

Agus Tunggal Saputra, I Wayan Bagia, N. N. Y. (2016). Pengaruh Kepuasan Kerja dan Loyalitas Karyawan Terhadap Kinerja Karyawan. Jurnal Manajemen Indonesia, 4(1), 1-8.

Astuti, R., \& Lesmana, O. P. A. (2018). Pengaruh Motivasi dan Beban Kerja terhadap Kinerja Perawat pada Rumah Sakit Umum Mitra Medika Medan. Jurnal Ilman, 6(2), 42-50.

Bandura, A. (1978). Self-Efficacy: Toward A Unifiying Theory Of Behavioral Chang. Journal of

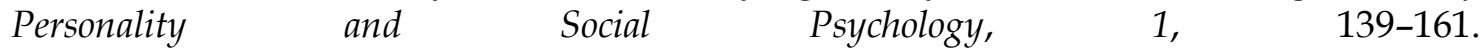
https:// doi.org/10.1017/S0003055400259303

Batchelor, O. (2017). Getting out the truth: the role of libraries in the fight against fake news. Reference Services Review, 45(2), 143-148. https:// doi.org/10.1108/RSR-03-2017-0006

BorjAlilu, S., Kaviani, A., Helmi, S., Kabakhsh, M., \& Mazaheri, M. A. (2017). Exploring the Role of Self-Efficacy for Coping With Breast Cancer: A systematic Review. https://doi.org/10.19187/ABC.20174242-57

Cason, M., Atz, T., \& Horton, L. F. (2017). New Nursing Graduates' Self-Efficacy Ratings and Urinary Catheterization Skills in a High-Fidelity Simulation Scenario. Clinical Simulation in Nursing, 13(2), 71-77. https:/ / doi.org/https:/ / doi.org/10.1016/j.ecns.2016.12.006

Coughlan, M. and P. C. (2017). Doing a Literature Review in Nursing, Health and Social Care (2nd ed.). sage publication inc.

Dewi Octavia Tumurang, Ventje Ilat, M. Y. . K. (2019). Pengaruh Self Efficacy, Kompleksitas Tugas Dan Keahlian Audit Terhadap Audit Judgment Auditor Pada Inspektorat Provinsi Sulawesi Utara. Jurnal EMBA: Jurnal Riset Ekonomi, Manajemen, Bisnis Dan Akuntansi, 7(3), 3919-3928.

Fatimah, F. S., \& Rosa, E. M. (2016). Efektivitas Pelatihan Patient Safety; Komunikasi S-BAR pada Perawat dalam Menurunkan Kesalahan Pemberian Obat Injeksi di Rumah Sakit PKU Muhammadiyah Yogyakarta Unit II. Jurnal Ners Dan Kebidanan Indonesia, 2(1), 32. https://doi.org/10.21927/jnki.2014.2(1).32-41

Genuino, M. J. (2018). Effects of simulation-based educational program in improving the nurses' self-efficacy in caring for patients' with COPD and CHF in a post-acute care (PACU) setting. Applied Nursing Research, 39, 53-57. https://doi.org/10.1016/j.apnr.2017.10.012

Gibson, James L., Donnelly Jr, James H., Ivancevich, John M., K., \& Robert. (2012). Organizationa Behavior, Structure, Processes (14th ed.). New York: Avenue of The Americas,.

Hadinata, D., Wahyuni, S., \& Putri, D. I. N. (2019). Kinerja Perawat Di Ruang Rawat Inap Rsud Cideres Kabupaten Majalengka Tahun 2018. Jurnal JKeperawatan Dan Kesehatan MEDISNA AKPER YPIB Majlaengka, V, 1-12.

Hutahaean, S. (2020). Standar Kompetensi Kerja Perawat. Media Sains Indonesia. Bandung

Jannah, M. M., Supriadi, N., \& Suri, F. I. (2019). Efektivitas Model Pembelajaran Visualization Auditory Kinesthetic (Vak) Terhadap Pemahaman Konsep Matematis Berdasarkan Klasifikasi Self-Efficacy Sedang Dan Rendah. AKSIOMA: Jurnal Program Studi Pendidikan Matematika, 8(1), 215-224. https:// doi.org/10.24127/ajpm.v8i1.1892

Jeeza, H., Hongkrailert, N., \& Sillabutra, J. (2015). Effect of efficacy on nursing performance in Indira Gandhi Memorial Hospital, Maldives. Journal of Public Health and Development, 13(2), 33-44.

Kurniadi, A. (2016). Manajemen Keperawatan dan Prospektifnya (II). Jakarta: Fakultas Kedokteran Universitas Indonesia.

Library, M. (2017). Currency: Relevance: Authority: Accuracy : Purpose : (March), 2017.

Mahmudi, M. H., \& Suroso, S. (2015). Efikasi Diri, Dukungan Sosial dan Penyesuaian Diri Dalam Belajar. Persona:Jurnal Psikologi Indonesia, 3(02), 183-194. https://doi.org/10.30996/ persona.v3i02.382 
McDonough, K., Crimlisk, J., Nicholas, P., Cabral, H., Quinn, E. K., \& Jalisi, S. (2016). Standardizing nurse training strategies to improve knowledge and self-efficacy with tracheostomy and laryngectomy care. Applied Nursing Research: ANR, 32, 212-216. https://doi.org/10.1016/j.apnr.2016.08.003

Neely-Sardon, A., \& Tignor, M. (2018). Focus on the facts: A news and information literacy instructional program. Reference Librarian, 59(3), 108-121. https://doi.org/10.1080/02763877.2018.1468849

Notoatmodjo, S. (2018). Metodologi Penelitian Kesehatan. Jakarta: Rhineka Cipta.

Nursalam. (2020). Pedoman Penyusunan Literature Review dan Systematic Review (D. Priyantini, ed.). Surabaya.

Oh, H. S., \& Wee, H. (2016). Self Efficacy, Organizational Commitment, Customer Orientation and Nursing Performance of Nurses in Local Public Hospitals. Journal of Korean Academy of Nursing Administration, 22(5), 507. https:/ / doi.org/10.11111/jkana.2016.22.5.507

Palareti, G., Legnani, C., Cosmi, B., Antonucci, E., Erba, N., Poli, D., ... Tosetto, A. (2016). Comparison between different D-Dimer cutoff values to assess the individual risk of recurrent venous thromboembolism: Analysis of results obtained in the DULCIS study. International Journal of Laboratory Hematology, 38(1), 42-49. https://doi.org/10.1111/ijlh.12426

Pranesia Kurniawati, Nina Widowati, A. R. (2017). Analisis Kinerja Pegawai Di Kantor Kecamatan Sarang Kabupaten Rembang. 6(1), 74-79.

Rayatin, L. (2018). Model Kepemimpinan Servant Paling Dominan Berhubungan dengan Kinerja. Jurnal Keperawatan Indonesia, 21(3), 180-188. https://doi.org/10.7454/jki.v21i3.773

Reid, C., Jones, L., Hurst, C., \& Anderson, D. (2018). Examining relationships between sociodemographics and self-efficacy among registered nurses in Australia. Collegian, 25(1), 57-63. https:/ / doi.org/https:/ / doi.org/10.1016/j.colegn.2017.03.007

Renny Triwijayanti1, Romiko2, S. S. D. 3. (2020). Hubungan Masalah Tidur dengan Kinerja Perawat di Rumah Sakit. 11(1), 95-99.

Ridley, D. (2012). The Literature Review: A Step-by-Step Guide for Students (2nd ed.). SAGE.

Rivai, Muhammad Abduh, F., \& Kadir, R. (2018). Pengaruh role stress, self efficacy, adaptability, terhadap kinerja perawat di rumah sakit pupuk kaltim siaga ramania samarinda. 2(1), 201-207.

Rusyana, D. (2017). Analisis Pengaruh Pengembangan Karier Terhadap Kinerja Pegawai Pada Badan Perencanaan Pembangunan Daerah. Journal of Chemical Information and Modeling, 8(9), 1-58. https://doi.org/10.1017/CBO9781107415324.004

Seham Mohamed Abd Elhamed, S. M. M. \& A. S. M. (2019). Relationship between Head Nurses' Job Performance and Staff Nurses' Commitment. Port Said Scientific Journal of Nursing, 6(1), 261-277. https:// doi.org/10.21608/pssjn.2019.35074

Wowor, M. (2019). Hubungan Kinerja Perawat Dengan Kepuasan Pasien Di Instalasi Gawat Darurat Rsu Gmim Pancaran Kasih Manado. Hubungan Kinerja Perawat Dengan Kepuasan Pasien Di Instalasi Gawat Darurat Rsu Gmim Pancaran Kasih Manado, 7(1), 1-7. 